\title{
Икономически, социални и здравни аспекти на операциите по повод девиация на носната преграда (клинична пътека 124)
}

\author{
Н. Станчева \\ Икономически университет - Варна, \\ Катедра "Международни икономически отношения"
}

\begin{abstract}
There is an increasing trend in day-surgery procedures worldwide. In this paper we suggest that the septoplasty (clinical pattern 124) could be transferred to one day surgery and this will lead to increasing cost-efficiency. The surgeon's professional skills and the appropriate selection of the patients are crucial for the good outcome of the procedure. We made some recommendations to improve the procedure's outcomes.
\end{abstract}

Keywords: septoplasty, one-day surgery

\section{Резюме}

В световен мащаб се увеличава дельт на еднодневната хирургия в различни области на хуманната медицина. В статията се предлага септопластиката да бъде осъществявана в определени случаи и като еднодневна хирургия. От значение за добрия изход на операцията са професионалните умения на хирурга и правилния подбор на пациентите. Направени са препоръки за подобряване на резултатите от процедурата.

Ключови думи: септопластика, еднодневна хирургия

\section{Увод}

В последните десетилетия в световен мащаб ясно се откроява тенденцията за намаляване на продължителността на хоспитализация и увеличаване на дела на еднодневната хирургия. В голяма степен това се дължи на техническите и научните постижения на медицинската практика, а също така и на редица културни и икономически фактори.

В България паричните еквиваленти на редица клинични пътеки, особено в областта на оториноларингологията, са оценени изключително ниско от здравната каса, което води до неадекватното заплащане на труда на здравните служители и специалистите в болничната помощ. За разлика от техните колеги в доболничния сектор, специалистите в болничния сектор се наемат от здравните заведения, които са търговски дружества. Доходите на медицинския персонал и условия на труд зависят от качеството на болничния мениджмънт [1]. През последните години разликата между заплащането на лекарите в болничния и доболничния сектор се увеличи значително. В редица случаи стойността на клиничните пътеки не покрива консумативите за болнична помощ, а в други определените изисквания за болничен престой не съответстват на вида на оперативната интервенция.

В условията на финансова криза и при очевидното нежелание на управляващите да решат проблема следва да се търсят други възможности на вътрешни резерви и оптимизиране на болничната помощ.

\section{Дискусия}

Опитите за преодоляване на проблема с неадекватното заплащане на труда в болничния сектор досега 
ce свеждат до деконцентрация на управлението на публичното здравеопазване и делегиране на повече права и отговорности на ръководствата на болниците. Принципалът във всички случаи е държавата (Министерство на здравеопазването) или общината, която назначава борда на директорите и приема рамката на колективния трудов договор, в който се уточняват равнищата на заплащане. Бордът на директорите има сравнително голяма свобода на действие относно разпределението на фонд работна заплата. Националният рамков договор гарантира, че той се формира от не по-малко от $40 \%$ от постьпленията от НЗОК по клиничните пътеки. При неадекватното заплащане по клиничните пътеки тази регулаторна уредба на практика връзва ръцете на болничния мениджмънт по отношение на инвестиции и закупуване на медикаменти и опосредстващи услуги. В бюджета за болнична помощ за 2009 година са заложени около 1 милиард лева, но като се има предвид очакваният инфлационен натиск, неблагоприятната демографска структура на населението, увеличаващата се заболеваемост от остри и хронични болести и неефективният мениджмънт на места, може да се твърди, че тези средства ще са недостатъчни да покрият нуждата от финансиране. Номинално сумата на предвидените средства отбелязва ръст с 300 милиона лева спрямо 2008 г., но като съотношение се намалява размерът на предвидените разходи за болнична помощ. В допълнение на това над 400 милиона лева, предназначени за здравеопазване, ще бъдат замразени в качеството на буфер в държавния резерв. Всички гореизброени факти налагат необходимостта да се потьрсят ефективни решения за минимизиране на разходите в болничната помощ.

Считаме, че клиничната пътека хирургично лечение на затрудненото носно дишане и в частност - септопластика, особено ако бъде осъществена според съвременните изисквания за хирургия на носната преграда, може напълно да съответства на изискванията за еднодневна хирургия. Средно на година в клиниката по оториноларингология към Университетска болница „Света Марина“ - Варна, се извършват около 100 корекции на назалния септум. Според действащите изисквания на НЗОК минималният престой в болничното заведение трябва да е 3 дни. Ако хирургичната интервенция септопластика бъде извършвана като еднодневна хирургия, съответно спестените средства ще възлизат на 200 леглодни, или около 20000 лева за година.

Неефективно се оказа от практиката, че в повечето случаи изискванията за минимален болничен престой в болничните заведения са несъобразени с действително изискуемия минимум. Това води до натрупването на ненужни разходи, свързани с болничния престой на пациентите и грижите по тяхното възстановяване, медикаменти, консумативи, разходи за електрическа енергия, вода и други. Осъществяването на операцията по повод девиирана носна преграда (септопластика) като еднодневна хирургия ще има редица позитивни ефекти. Икономическата изгода не е само за лечебното заведение, а и за самото общество - пациентът възвръща по-бързо своята трудоспособност. Освен това целта на еднодневната хирургия е да се намали психическата и физическата травма. Според Европейския здравен индекс България има най-неприятелската към пациентите здравна система. Намаляването на продължителността на болничния престой ще направи субективните усещания на пациентите след операцията по-комфортни. Отдавна е доказано, че ако се долекуваш в обкръжението на близките си, това има много по-бърз оздравителен ефект. При оперативните интервенции с по-дълъг болничен престой се увеличава рискът от вътреболнични инфекции. Еднодневната хирургия свежда този риск до минимум. В свое изследване Agha, Heaton и Roberts показват, че в 84 до 94\% от случаите септопластиката е подходяща като еднодневна хирургия. [3] В същата публикация се посочва, че значителна част от пациентите със септопластика са се почувствали субективно готови да напуснат болничното заведение в деня на операцията. Във високоразвитите страни - САЩ, ЕС и Япония, еднодневната хирургия се развива от десетилетия. Считаме, че в България съществуват редица неизползвани възможности за въвеждане на този вид процедури, като напълно е реалистично всяко болнично лечебно заведение да има отделение за еднодневна хирургия. Според български експерти у нас професионалното равнище на лекарите отговаря на изискванията за провеждането на еднодневна хирургия. В момента еднодневната хирургия се финансира от НЗОК по клиничните пътеки на общата хирургия. След като в САЩ е въведена еднодневната хирургия, броят на тези процедури нараства за съвсем кратко време седем пъти. За България такъв пример може да се даде с Университетска болница „Св. Марина“ в гр. Варна. За осъществяване на еднодневна хирургия са осигурени 1142000 евро, като от тях 850000 евро са инвестирани в специализирана апаратура. Само за 10 дни са направени 480 операции.

Изискванията за минимален брой изследвания са очевидно недоглеждане и нарушение на добрата медицинска практика. Така например изискването 
за рентгенография на нос и околоносни кухини при операция на носната преграда е абсолютно ненужно. То няма да онагледи или демонстрира девиация, тъй като визуализацията на носната преграда е твърде относителна и няма клинична стойност. На тази основа често рентгенологьт отбелязва в заключението си, че няма данни за девиация на носната преграда, което компрометира клиничния преглед и диагноза. Условието да се провеждат предоперативните изследвания в болницата пренатоварва персонала с ненужни манипулации и лабораторни разходи. При изследвания, сочещи противопоказания за операцията, пациентът следва да бъде изписан и историята на заболяването анулирана, което е още един ненужен разход за болничното заведение. За да бъде избегнато това, е необходимо да се изисква пациентьт да се яви с предварително изготвени изследвания и едва тогава да се насрочи операцията. Описанието на оперативната интервенция често буди основателни несъгласия на хирурзите и изисква от тях компромис с професионалната етика. Това е така, защото като оперативна процедура е определена „Субмукозна резекция на назалния септум“", код 21.5. Това е оперативна интервенция, която е предложена от Killian през 1904 година и днес нейните недостатъци и усложнения налагат ограничаването ѝ. Субмукозната резекция на назалния септум още след 1960 година е изместена от по-модерната и атравматична септопластика [4]. Септопластиката е процедура, която се отнася щадящо към структурите на носната преграда и позволява по-кратьк следоперативен възстановителен период.

Анализите сочат, че от особена важност за добрия изход от операцията е сътрудничеството между лекар и пациент, което допринася за значително съкращаване на продължителността на хоспитализацията. [5]

\section{Литература:}

1. Попова, Е. „Болниците погльщат най-много от средствата за здраве“ вестник „Класа“ 2008-10-03;

2. Недев П. Септопластика. ИК „Геа-принт“ - Варна 2008. ISBN 978-954-9430-35-6.

3. Agha, R., Heaton, S. and Roberts, D. Patient satisfaction with day-case septoplasty and septorhinoplasty The Journal of One-Day Surgery, 2006; 4(2):80-81

\section{Препорьки}

На първо място трябва да извърши внимателен подбор на пациентите, подходящи за еднодневна хирургия на носната преграда. Необходима е строга преценка на индикациите за септопластика, като подходящи за еднодневна хирургия са пациенти, при които липсват придружаващи заболявания. Еднодневната хирургия е препорьчителна при хора в активна трудоспособна възраст.

Второ, предвиденото време за оперативна интервенция трябва да е рано сутринта, тъй като е добре да се осигури повече време за следоперативно наблюдение в болничното заведение.

Задължително е пациентът да бъде запознат подробно с възможностите на процедурата.

\section{Заключение}

Оптимизъм буди фактът, че в Министерството на здравеопазването е внесен проект за стандарти за еднодневна хирургия от Българското хирургическо дружество. Проектьт съдържа ясни процедури за изискванията на този вид интервенции. Сериозни са различията между здравната каса и лекарите по повод финансирането на проекта. Клинична пътека 124 - хирургично лечение на затруднено носно дишане и в частност корекция на девиация на носната преграда, е подходяща за въвеждане и прилагане на еднодневна хирургия. Интервенцията се понася леко и пациентите могат да се обслужват сами няколко часа след операцията. Най-важните условия за успех на процедурата са професионалните умения на хирурга и правилният подбор на кандидатите за септопластика.

4. Nedev P. Cranio-caudal transdomal sutures for the nasal tip correction. European Archives of Oto-Rhino-Laryngology and Head \& Neck, Volume 266, Number 2 / February, 2009, pp 1434-4726;

5. Singarelli, S., Berni, G., Coppo, P. and Francchia, D. Day-surgery, one-day surgery: the experience of an ENT Unit in a 250 bed Hospital Acta otorhinolaryngol Ital 25, 2005, 365-369 